\title{
How have Mergers and Acquisitions Affected Financial Performance of Firms in Indian Manufacturing Sector?
}

\author{
Pulak MISHRA*
}

Received: May 22, 2018

Revised: December 25, 2018

Accepted: April 25, 2019.

\begin{abstract}
The paper examines how mergers and acquisitions (M\&As) in India after initiation of reforms in 1991 have affected firms' financial performance. Using panel data and applying the method of difference GMM, it is found that neither market concentration nor M\&As affected firms' financial performance because of the multidirectional structure-conduct-performance relationships. Instead, interindustry differences in performance have been caused by capital intensity, efforts relating to marketing and distribution, and foreign technology. The findings suggest for a relook at the competition policies and laws, international trade, investment and technology development as they influence financial performance through market structure along with firms' business strategies, efficiency and competitiveness.
\end{abstract}

Keywords: Reforms, mergers and acquisitions, financial performance, competition policy, manufacturing sector, India

JEL Code Classification: D4, L1, L2, L4

UDC: 331.445

DOI: https://doi.org/10.17015/ejbe.2019.023.05

\footnotetext{
* Indian Institute of Technology Kharagpur, India. Email: pmishra@hss.iitkgp.ac.in 


\section{Introduction}

Initiation of reforms has changed the business conditions in India considerably. Despite its slow pace in recent years, the reform measures in general have continued aiming at enhanced competition in different markets. In response to various policy and regulatory changes, the domestic firms have consolidated operations through mergers ${ }^{1}$. On the contrary, the foreign firms have preferred acquisitions for their entry into Indian markets. Consequently, the number of deals ${ }^{2}$ has increased significantly (Beena, 2014; Basant \& Mishra, 2016). It is also observed that the multinational corporations (MNCs) have taken active part in acquisitions and it has been an important channel of inward foreign investments ${ }^{3}$.

A widely addressed and debated research issue is, how M\&As affect firms' financial performance, and the existing studies are not conclusive in the regard. It is hypothesized that M\&As improve financial performance through either monopoly power or greater efficiency ${ }^{4}$. It is also possible that M\&As enhance efficiency in the short-run which leads to long-run monopoly power. According to Bain (1956), given the market structure, M\&As influence firms' performance. Studies by Healy, Palepu, and Ruback (1992), Smart and Waldfogel (1994), Switzer (1996), Vander (1996), Manson et al. (2000), Heron and Lie (2002) and Rahman and Limmack (2004) support the proposition that M\&As enhance business performance ${ }^{5}$. However, it is also found that performance deteriorated after M\&As (e.g., Mueller, 1985; Ravenscraft \& Scherer, 1987; Dickerson et al., 1997; Ghosh, 2001; Sharma \& Ho, 2002; Yeh \& Hoshino, 2002; Schenk, 2006). Similarly, Ikeda and Doi (1983), Cosh et al. (1984), Kumar (1984), Geroski (1988), Odagiri (1992), Pawaskar (2001), Gugler et al. (2003) Powell and Stark (2005), and Akin and Bayyurt (2016) found either negative impact or no change as such in post-merger or post-acquisition performance.

Thus, the findings relating to influence of M\&As on performance are inconsistent, and there is need to revisit the relationships. It is more pertinent in Indian context as there is barely any improvement in performance after introduction of liberal policies (Basant \& Mishra, 2016). At the same time, sellers' concentration in markets showed either decline or no change in many industries (Mishra \& Rao, 2014). Further, greater concentration does not necessarily influence performance in a dynamic context (Mishra, 2008). On the contrary, M\&As have enhanced export

\footnotetext{
${ }^{1}$ In particular, firms with excess capacity and higher innovative efforts depend largely on mergers to consolidate market positions (Vyas, et al., 2012).

${ }^{2}$ The present paper does not distinguish between mergers from acquisitions due to their similar economic and financial implications.

${ }^{3}$ Cross-border deals had a share of 34 percent in M\&As during 2000-2008 (Saraswathy, 2015). Further, acquisitions had 27 percent share in inflows of equity during 2000-2012 (ISID, 2014).

${ }^{4}$ When seen in this line, impact of M\&As on performance is determined by the anti-competitive effect of market power (Stigler, 1950) and pro-competitive impact of efficiency (Williamson, 1968).

${ }^{5}$ Evidences show positive returns from cross-border acquisitions (Zhu \& Malhotra, 2008; Karels, et al., 2011).
} 
How have Mergers and Acquisitions Affected Financial Performance of Firms in Indian...

competitiveness (Mishra \& Jaiswal, 2017). Besides, India has also emerged as foreign direct investor in recent years (Pradhan, 2008) ${ }^{6}$.

The above developments in Indian industry sector are quite complex. This creates the necessity of examining how M\&As have affected business performance given the ongoing processes of policy and regulatory changes and subsequent strategic conjectures, particularly for the following reasons: First, while cost-efficiencies do not show any evidence of improvement ${ }^{7}$, export intensity has gone up in major industries with marginal decline in imports (Basant \& Mishra, 2016). On contrary, financial performance, particularly profitability shows sign of improvement only at a very slow rate. Hence, the influence of $M \& A s$ on performance is not very clear.

Second, there are evidences of M\&As failing to improve financial performance in Indian context. For example, M\&As did not affect profitability of pharmaceutical companies (Mishra \& Chandra, 2010). Instead, their financial performance varied directly with asset base, selling expenses and international trade, but inversely with demand and firms' relative position in the market (Mishra \& Chandra, 2010). Similarly, it is found that mergers could not generate high monopoly rents or impede the competitive process (Saple, 2000), whereas there are evidences of rise in post-merger average sales and net worth with very less proportion of firms experiencing a decline in profitability (Das, 2000).

Third, M\&As may not impact financial performance when other business strategies as well as various market structure and policy related aspects are also considered. Policy and regulatory changes in respect of competition, private investment, international trade, intellectual property, etc. are expected to influence firms' strategic responses, market structure and performance. When it is so, performance enhancing effects of M\&As may not be significant. Furthermore, since M\&As depend on specificities of different industries (Mitchell \& Mulherin, 1996) and the distribution of deals as well as financial performance have varied across industries (Basant \& Mishra, 2016), assessment of impact at industry level is very important.

Given this backdrop, the present paper examines how M\&As in India have caused inter-industry differences in financial performance. The paper has five sections. While the next section deals with model specification, the subsequent section discusses the techniques applied for model estimation. Besides, data sources are mentioned here. Regression results along with their implications are analyzed in the forth section. It also hypothesizes how the explanatory variables can influence performance. The last section highlights the major findings and draws the policy and regulatory issues.

\footnotetext{
${ }^{6}$ It is found that M\&As had positive impact on incidence export as well as its intensity even at firm level (Mishra \& Jaiswal, 2017).

${ }^{7}$ However, there are evidences of greater efficiencies in respect of costs of the banks after mergers in India (Kaur \& Kaur, 2010)
} 


\section{Model Specification}

Following the modified relationships amongst market structure, business conducts and performance (SCP) as postulated by Scherer and Ross $(1990)^{8}$ and subsequent developments in the literature, the conceptual framework in Figure 1 is envisaged to understand how M\&As have affected financial performance in different industries. The proposed framework considers M\&As as conducts and examines the impact on financial performance taking influences of market structure, other strategies and policy and regulatory changes into consideration. For example, exports, advertising and marketing related efforts and innovation can cause significant positive impact on performance (Tyagi \& Nauriyal, 2016). Similarly, performance can also be affected by capital intensity (Kambhampati \& Parikh, 2003).

Furthermore, previous performance can also influence its current level through various feedback effects. In addition, the relationships amongst many of these variables are not instantaneous Kambhampati (1996). For instance, M\&As can influence financial performance only after an interval as settlement of the deals and reaping the outcomes require time. Similarly, in-house R\&D efforts have gestation lags to result in new product or process and influence performance. All these essentially result in a dynamic framework (Figure 1).

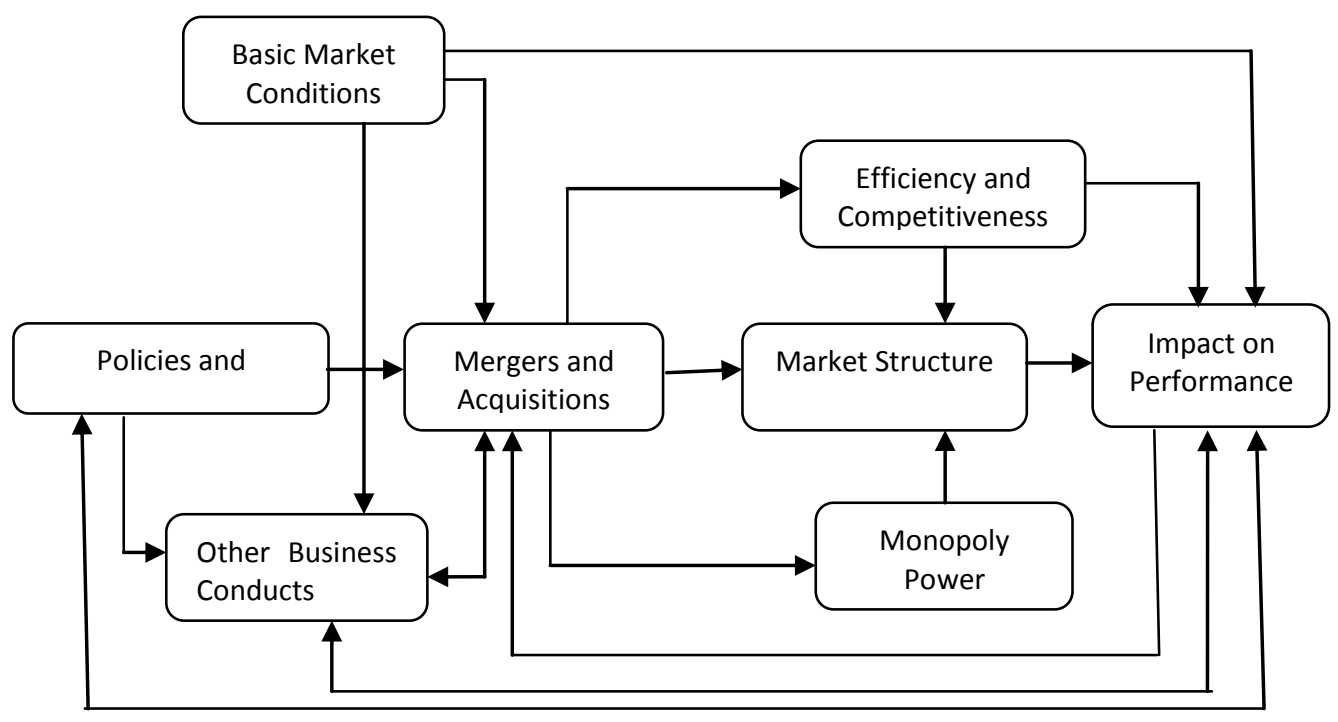

Figure 1. The Analytical Framework

Source: Based on Scherer and Ross (1990) and Basant and Mishra (2019)

\footnotetext{
${ }^{8}$ The initial unidirectional SCP framework was propounded by Bain (1956).
} 
Accordingly, current financial performance $\left(P E R_{t}\right)$ is assumed to depend on present market concentration $\left(C O N_{t}\right)$, current capital intensity $\left(K_{\mathrm{R}}\right)$, present import-export ratio $\left(I M E X_{t}\right)$, lagged $M \& A s\left(M \& A_{t-1}\right)$, current advertising intensity $\left(A D V T_{t}\right)$, present marketing and distribution intensity $\left(M A D_{t}\right)^{9}$, lagged in-house $R \& D$ intensity $\left(R \& D_{t}\right.$ $\left.{ }_{1}\right)$, current intensity of foreign technology purchase $\left(\mathrm{FTP}_{\mathrm{t}}\right)$, and lagged financial performance $\left(P E R_{t-1}\right)$, i.e.,

$$
P E R_{i t}=f\left(P E R_{i, t-1}, K_{i t}, C O N_{i t}, M \& A_{i, t-1}, A D V T_{i t}, M A D_{i t}, R \& D_{i, t-1}, F T P_{i t}, I M E X_{i t}\right)
$$

While $\mathrm{CON}_{\mathrm{t}}, \mathrm{KIR}_{\mathrm{t}}$ and IMEX $\mathrm{t}$ are used as proxies for structural aspects of the market, $M \& A_{t-1}, A D V T_{t}, M A D_{t}, R \& D_{t-1}$ and $F T P_{t}$ stand for conducts and $P E R_{t-1}$ for past performance. In addition, $M \& A_{t-1}$ proxies changes in policies for investment and competition. Similarly, IMEX $\mathrm{t}$ controls influence of policies for international trade, whereas $R \& D_{t-1}$ and $F T P_{t}$ act as proxies for policies relating to technology including intellectual property rights.

Here, effect of the deals on performance is examined in respect of profitability (PROF) and returns on capital employed (ROCE). While profitability shows relationship between profits and output or sales, rate of returns reflects its association with investments. These two alternative proxies ensure robust findings. The paper measures PROF and ROCE as ratio of profit before tax to sales and capital employed respectively. Here, the number of deals over last three years in natural logarithm is taken as the measure of $M \& A s^{10}$. The Herfildahl-Hirschman Index $(\mathrm{HHI})$ is computed for market concentration. Other variables in intensity are with respect to sales.

\section{Data and Econometric Techniques}

Thus, financial performance depends on several factors and assessing impact of $M \& A s$ in this regard requires controlling their influence through appropriate econometric modelling. The relationships envisaged here are empirically examined by estimating dynamic panel data models with 84 industries for the period 20012002 to $2010-11^{11}$. The timeframe for the study is selected based on large scale participation of the MNCs in M\&As and modifications to the country's regulatory norms along with (iii) stable macroeconomic conditions (Mishra 2018). However, timeframe beyond $2010-11$ is not considered due to the slow pace of deals during

\footnotetext{
9 The present paper considers marketing and distribution related expenditures separately from adverting. While advertising leads to differentiation in products and entry barriers, emphasis on promotional activities and distribution channels results in complementary assets. Hence, their impact on performance may differ.

${ }^{10}$ Since the numbers of M\&As are discrete in nature and hence have scale effects, natural logarithm of the number of deals is taken, instead of their actual numbers.

${ }^{11}$ Hence, this paper carries out industry level analysis. These selected 84 industries cover majority of the sector at 3-digit level of industrial classification and have regular evidences of M\&As taking place therein. Further, these 84 industries have relatively less missing observations during the study period. Hence, the selected sample appears to be comprehensive.
} 
2008-14 (Basant \& Mishra, 2016). The Prowess IQ database of the Centre for Monitoring Indian Economy (CMIE) is used to source data and information.

According to Arellano and Bover (1995) and Blundell and Bond (1998), system GMM method enhances estimators' efficiency. However, the paper is based on difference GMM as suggested by Arellano and Bond $(1991)^{12}$. Since the number of panel units is very large, the method of difference GMM would result in consistent estimators. On the contrary, application of the method of system GMM and incorporating additional moment restrictions under such conditions may lead to larger instruments and over fitting of endogenous variables ${ }^{13}$. Here, one-year lag of the variables are used as the instruments ${ }^{14}$.

Further, significance of overall models is tested and inferences on coefficients are drawn using the two-step and one-step estimators respectively. The variance inflation factors (VIFs) signal if multicollinearity is severe. With the dataset being unbalanced panel, stationary nature of the variables is examined using Fisher-type test. When the null hypothesis is rejected, at least one panel is stationary. The paper uses Augmented Dickey-Fuller (ADF) as well as Phillips-Perron (PP) tests with inverse and modified inverse $\chi^{2}$ statistics and trend components. However, the drift is not added as the mean of financial performance may not be different from zero. Further, demeaning removes the means of cross-sectional units. Furthermore, the plug-in procedure of Newey and West (1994) is used to select the lag length.

However, unlike some other industry level studies (e.g., Mishra \& Basant 2017; Mishra, 2018), the paper is not based on moving averages of variables. This is so because financial performance may have temporal variations and averaging of variables may reduce such changes leading to distorted results.

\section{Regression Results and Discussions}

\subsection{Possible Impact of Explanatory Variables}

The related literature portrays diverse impact of the explanatory variables on firms' financial performance. Analyzing the regression results require deeper understanding of how these variables can potentially affect performance and their measurements. It is observed that firms realize supernormal profit in a concentrated market (Bain, 1951; Stigler, 1964). While the studies by Weiss (1974) and Goldar and Aggarwal (2004) support such a positive relationship, its extent may vary depending on business conducts (Mishra, 2008). However, concentrated market may not be necessary for better financial performance when firms have superior efficiency (Demsetz, 1973). Similarly, greater control over market may not

\footnotetext{
${ }^{12}$ The details on the method of difference GMM and its advantages over the method of instrumental variable are summarized in Mishra (2018).

${ }^{13}$ With industry being the panel unit, endogeneity problem is expected to be less acute.

${ }^{14}$ With large panel units and smaller timeframe, estimation of such a dynamic model results in consistent estimators.
} 
ensure better performance when entry barriers are weak (Hay \& Morris, 1991). How market structure would influence performance over time depends on the strength of these factors (Mishra, 2008).

As regards capital intensity, it results in entry barriers and monopoly profits (McDonald, 1999; Demir, 2013). Global competitiveness of firms may also improve with increase in capital intensity. However, high capital intensity limits adjustments to shocks. Besides, large capital intensive firms make smaller entities less competitive due to capital market imperfections (Basant \& Saha, 2005). Thus, impact of capital intensity on performance is ambiguous.

Evidences also show that while M\&As can lower production costs through economies of scale (Porter, 1985; Shelton, 1988), they can also enhance monopoly power (Steiner, 1975, Chatterjee, 1986). Hence, M\&As can improve performance through monopoly power and/or efficiency. However, given the multidirectional SCP relationships (Scherer \& Ross, 1990), financial performance may also be affected by structural aspects of markets, conducts other than M\&As, previous performance and governments' interventions. Thus, when these factors are considered, M\&As may fail to improve performance.

Advertising results in brand image. It also leads to product differentiation and entry barriers (Comanor \& Wilson, 1967). Hence, greater emphasis on advertising would improve performance. Evidences show (e.g., Scherer \& Ross, 1990; Bhagwat \& Bruine, 2011) positive association between profitability and advertising. However, advertising may not affect performance (Grabowski \& Mueller, 1978; Delorme et al., 2002), particularly when it is informative. On the contrary, efforts towards promotion or distribution help to reach the consumers easily and in time. This eventually improves financial performance. There are evidences of improvement in performance with increase in such efforts (Majumdar, 1997; Bhagwat \& Bruine, 2011).

Similarly, innovation strengthens presence in existing markets and creates new opportunities. It can also restrict entry (Mueller, 1990) leading to higher profitability (Cefis 1998; Scherer, 2001). However, when regulatory structure is weak, there may be imitation of innovation outcomes. Hence, impact of innovation on performance is not conclusive. For example, innovation had no effect on profitability of Indian pharmaceutical firms (Mishra \& Chandra, 2010; Mishra \& Vikas, 2010).

Likewise, sourcing technologies from abroad lowers costs of operations and hence prices (Balcer \& Lippman, 1984) along with enhancing product quality and demand in domestic markets. It also creates strategic entry barriers. All these are likely to improve financial performance. However, reaping the benefits also requires proper application of the technologies acquired and development of complementary technologies. Further, if foreign technologies are obsolete, domestic firms may not benefit vis-à-vis the MNCs. 
One may expect that better financial performance would strengthen market positions and develop various complementary assets. This is expected to improve incumbents' future performance and induce potential entry raising competition and downward pressures on financial performance, particularly when entry barriers are not effective. Better performance in the past can also cause adverse impact through X-inefficiency. The paper uses one-year lag of profitability and returns on capital employed as alternative measures of lagged financial performance.

Finally, more imports increase competitive pressures. This can potentially improve efficiency and performance (Majumdar, 1997). It is also expected that exports would make performance better through greater efficiency and competitiveness (Majumdar, 1997; Wagner, 2012, Vu et al., 2014). For example, Saluja (1968) and Katrak (1980) found improvement in performance with less competition from imports and greater penetration in export markets. Further, evidences also show (e.g., Kongmanila et al., 2009; Grazzi, 2010) inconclusive relationships between exports and profitability. Hence, impact of import-export ratio on financial performance is not clear.

\subsection{Findings and Implications}

Table 1 summarizes the variables and Table 2 gives the partial correlation coefficients. It is found that, except the import-export ratio, other explanatory variables have statistically significant partial association with either of the two alternative measures of financial performance, though significance level and the nature of correlation differ across the indicators. Notably, M\&As have positive (partial) association with ROCE, for some of the variables whereas it is not so for profitability. Further, low values of variance inflation factors suggest no multicollinearity problem (Table 2$)^{15}$.

Table 1. Summary Statistics

\begin{tabular}{llllll}
\hline Variable & $\begin{array}{l}\text { Number of } \\
\text { Observation }\end{array}$ & Mean & $\begin{array}{l}\text { Standard } \\
\text { Deviation }\end{array}$ & $\begin{array}{c}\text { Maximum } \\
\text { Value }\end{array}$ & $\begin{array}{l}\text { Minimum } \\
\text { Value }\end{array}$ \\
\hline PROF $_{t}$ & 840 & 840 & 0.051 & 0.085 & -0.520 \\
ROCE $_{t}$ & 840 & 840 & 0.070 & 0.096 & -0.433 \\
$\mathrm{HHI}_{\mathrm{t}}$ & 840 & 840 & 0.189 & 0.161 & 0.013 \\
$\mathrm{KIR}_{\mathrm{t}}$ & 840 & 840 & 0.917 & 0.483 & 0.232 \\
$\mathrm{MA}_{\mathrm{t}-1}$ & 840 & 815 & 1.959 & 1.001 & 0.000 \\
$\mathrm{ADVT}_{\mathrm{t}}$ & 827 & 827 & 0.013 & 0.020 & 0.000 \\
$\mathrm{MAD}$ & 840 & 840 & 0.054 & 0.035 & 0.005 \\
$\mathrm{RDt}_{\mathrm{t}}$ & 812 & 809 & 0.006 & 0.031 & 0.000 \\
$\mathrm{FTPt}_{\mathrm{IMEX}}$ & 700 & 698 & 0.031 & 0.073 & 0.000 \\
\hline
\end{tabular}

\footnotetext{
${ }^{15}$ Very low value of VIF for advertising intensity and marketing and distribution intensity (1.40 and 1.26 respectively) suggest their weak linear association controlling impacts of other factors.
} 
Table 2. Partial Correlation Coefficients

\begin{tabular}{llll}
\hline Independent Variable & \multicolumn{2}{l}{ Partial Correlation Coefficient } & VIF \\
& PROF & ROCE & \\
\hline $\mathrm{HHI}_{\mathrm{t}}$ & $0.2313^{* *}$ & $0.1905^{* *}$ & 1.58 \\
$\mathrm{KIR}_{\mathrm{t}}$ & 0.0573 & $-0.2690^{* *}$ & 1.28 \\
$\mathrm{MA}_{\mathrm{t}-1}$ & 0.0471 & $0.2086^{* *}$ & 1.61 \\
$\mathrm{ADVT}_{\mathrm{t}}$ & $0.0897^{* *}$ & $-0.1332^{* *}$ & 1.40 \\
$\mathrm{MAD}$ & $-0.0851^{* *}$ & 0.0573 & 1.26 \\
$\mathrm{RD}_{\mathrm{t}-1}$ & $0.1249^{* *}$ & $0.0690^{*}$ & 1.15 \\
$\mathrm{FTP}_{\mathrm{t}}$ & $0.1786^{* *}$ & 0.0382 & 1.33 \\
$\mathrm{IMEX}_{\mathrm{t}}$ & 0.0162 & 0.0066 & 1.02 \\
\hline
\end{tabular}

Note: ${ }^{* *}$ Significant at 5 percent; ${ }^{*}$ Significant at 10 percent

Here, the ADF test uses one-year lag for import-export ratio (IMEX). In case of inhouse R\&D, the Phillips-Perron test has been carried out without demeaning. The results suggest stationary nature of the variables (Table 3 ). In other words, there is no problem of unit roots and spurious regression. The findings are presented in Table 4 and 5 . In both the cases, the models are significant. Further, the Sargan test shows no over-identification problem, whereas the Arellano-Bond test indicates no autocorrelation of second order.

Table 3: Results of Unit Root Tests

\begin{tabular}{|c|c|c|c|c|}
\hline & \multicolumn{2}{|c|}{ Based on ADF Tests } & \multicolumn{2}{|c|}{ Based on PP Tests } \\
\hline Variable & Inverse $\chi^{2}$ & Modified Inverse $\chi^{2}$ & Inverse $\chi^{2}$ & Modified Inverse $\chi^{2}$ \\
\hline $\mathrm{PROF}_{\mathrm{t}}$ & 394.13 & 12.34 & 621.48 & 24.74 \\
\hline $\mathrm{ROCE}_{\mathrm{t}}$ & 419.69 & 13.73 & 296.08 & 6.99 \\
\hline $\mathrm{HHI}_{\mathrm{t}}$ & 283.73 & 6.31 & 249.73 & 4.46 \\
\hline $\mathrm{KIR}_{\mathrm{t}}$ & 436.62 & 14.65 & 279.64 & 6.09 \\
\hline $\mathrm{MA}_{\mathrm{t}-1}$ & 430.57 & 14.32 & 409.38 & 13.17 \\
\hline $\mathrm{ADVT}_{\mathrm{t}}$ & 647.79 & 26.44 & 378.91 & 11.69 \\
\hline $\mathrm{MAD}_{\mathrm{t}}$ & 563.65 & 21.58 & 404.49 & 12.90 \\
\hline $\mathrm{RD}_{\mathrm{t}-1}$ & 292.30 & 7.08 & 330.93 & 9.22 \\
\hline $\mathrm{FTP}_{\mathrm{t}}$ & 160.70 & 1.37 & 383.45 & 13.90 \\
\hline IMEX $_{\mathrm{t}}$ & 203.89 & 3.39 & 1183.66 & 59.17 \\
\hline
\end{tabular}

Notes: (1) In case of FTP, the Dickey-Fuller test statistics are significant at 10 percent, whereas the rests are significant at 5 percent; (2) In case of IMEX, 1 year lag is used for the ADF test. (3) The PP test for $R \& D$ is not mean corrected.

For both the models, the coefficients of capital intensity, marketing and distribution, and foreign technology are significant. Hence, these factors have caused inter-industry differences in financial performance. However, while the coefficient is positive for foreign technology purchase, it is negative in case of capital intensity and marketing and distribution related efforts. Thus, financial performance has been better in industries that have spent relatively more for purchasing foreign technologies. On contrary, capital intensive industries have 
recorded poor financial performance. The same can be said in case of marketing and distribution as well.

Table 4. Regression Results with Profitability as the Dependent Variable

\begin{tabular}{|c|c|c|c|c|}
\hline \multirow{2}{*}{ Variable } & \multicolumn{2}{|c|}{ Two-Step Estimates } & \multicolumn{2}{|c|}{ One-Step Estimates } \\
\hline & Coefficient & z-Statistic & Coefficient & z-Statistic \\
\hline Intercept & 0.0748 & $8.57^{* *}$ & 0.0908 & $3.80^{* *}$ \\
\hline PROF $_{\mathrm{t}-1}$ & 0.1258 & $4.53^{* *}$ & 0.1698 & 1.36 \\
\hline $\mathrm{HHI}_{\mathrm{t}}$ & 0.1536 & $5.39^{* *}$ & 0.1099 & 1.54 \\
\hline $\mathrm{KIR}_{\mathrm{t}}$ & -0.0339 & $-9.24^{* * *}$ & -0.0365 & $-3.05^{* *}$ \\
\hline $\mathrm{MA}_{\mathrm{t}-1}$ & 0.0010 & 0.42 & -0.0029 & -0.59 \\
\hline $\mathrm{ADVT}_{\mathrm{t}}$ & 0.4374 & $2.90^{* *}$ & 0.6535 & 1.26 \\
\hline $\mathrm{MAD}_{\mathrm{t}}$ & -0.6336 & $-8.44^{* *}$ & -0.6395 & $-3.33^{* *}$ \\
\hline $\mathrm{RD}_{\mathrm{t}-1}$ & -0.3586 & -1.27 & -0.1391 & -0.22 \\
\hline $\mathrm{FTP}_{\mathrm{t}}$ & 0.1141 & $17.55^{* *}$ & 0.1099 & $4.24^{* *}$ \\
\hline IMEX $_{\mathrm{t}}$ & 0.0005 & 1.46 & 0.0009 & $1.93^{*}$ \\
\hline Wald-Chi ${ }^{2}$ & $3240.67^{* *}$ & & $86.18^{* *}$ & \\
\hline $\begin{array}{l}\text { Sargan Test for Over- } \\
\text { Identification of Restrictions }\end{array}$ & $\begin{array}{l}43.59 \\
(0.15) \\
\end{array}$ & & & \\
\hline Arellano-Bond Test for AR (1) & $-1.98(0.05)$ & & $-2.41(0.02)$ & \\
\hline Arellano-Bond Test for AR (2) & $1.43(0.15)$ & & $1.57(0.12)$ & \\
\hline Number of Observations & 458 & & 458 & \\
\hline
\end{tabular}

In either case, coefficients of market concentration and M\&As are not significant implying that market concentration or M\&As have no influence on inter-industry variations in financial performance. In respect of M\&As, the findings are consistent with that of Mishra and Chandra (2010) and Mantravadi and Reddy (2008) in Indian context $^{16}$. Studies on other economies (e.g., Ikeda \& Doi, 1983; Geroski, 1988; Sharma \& Ho, 2002; Yeh \& Hoshino, 2002; Schenk, 2006) also found either negative or no effect on performance. However, the findings of this paper are contradictory to that of Healy et al. (1992), Grabowski et al. (1995), Switzer (1996), Smart and Waldfogel (1994), Vander (1996), Manson et al. (2000), Heron and Lie (2002) and Rahman and Limmack (2004) that reported improvement in post-merger performance. Such inconclusiveness is possibly because of multidirectional SCP relationships.

Thus, M\&As do not necessarily improve financial performance as it is found in many of the existing studies. The combinations may fail to raise firms' control over the market depending on the nature of integration or because of strategic conjectures by the rivals. For example, conglomerate M\&As may help in reducing business risks, but their impact on monopoly power or efficiency may not be so

\footnotetext{
${ }^{16}$ Notably, Mantravadi and Reddy (2008) found only minor changes in performance after M\&As.
} 
strong. Similarly, if the rivals are also engaged in M\&As, the potential benefits of integration may not be realized. The combinations might have also failed due to cultural differences and failures in rationalization of resources or reaching critical scale of operation. Further, wherever M\&As have improved efficiency or firms' control over the market, strategic conjectures and policy and regulatory interventions seem to have limited the benefits of M\&As in respect of achieving better financial performance. In addition, impact of M\&As on performance is also conditioned by industry specific factors and related policies.

Similarly, the finding in respect of market concentration is in the line of Mishra (2008), but contradictory to that of Kambhampati (1996) and Goldar and Aggarwal (2004). Possibly, absence of legal and strategic barriers coupled with high rate of economic growth has encouraged entry of new firms. This seems to have not only increased competition, but also created pressures on firms to provide various incentives to the consumers, making the relationship between concentration and financial performance weak. Furthermore, increasing competition has also resulted in business consolidation by firms for their survival, weakening the impact of concentration.

It is also found that both profitability and returns on capital employed varied inversely with efforts towards development of marketing and distribution related complementary assets. This is not only surprising, but also contradictory to Majumdar (1997) and Bhagwat and Bruine (2011). It is possible that the strategies have failed in reaching the consumers and hence delivering the desired outcomes. However, detailed scrutiny is necessary to understand why marketing and distribution related efforts failed in improving performance.

Similarly, advertising has failed to improve financial performance. This is very important given that the findings on impact of advertising on performance are not consistent in the literature. For example, Delorme et al (2002) could not find advertising affecting profitability, whereas Bain (1956) and Comanor and Wilson (1967) showed direct impact of selling efforts on the same. In Indian context also, advertisement intensity is considered as an important determinant of profit (Siddharthan \& Dasgupta, 1983). It is, therefore, necessary to understand why impact of non-price competition through advertising failed to influence financial performance and this can be an interesting area for further research.

Similarly, innovation does not alter performance and this is consistent with Mishra and Chandra (2010). However, this is contradictory to the findings of negative impact by Delorme et al. (2002) or positive relationship by Cefis (1998) and Scherer (2001). Possibly, the benefits are yet to be realized due to gestation lags or innovation efforts have failed. On the contrary, foreign technology purchase has enhanced financial performance. This is so possibly because new technologies can lower costs and prices (Balcer \& Lippman, 1984). In addition to enhancing competitive edge, it also creates entry barriers. However, the negative coefficient 
of capital intensity, though consistent with Bhandari (2010), differs from the findings of positive impact by Liebowitz (1982) and Martin (1988).

Table 5. Regression Results with Returns on Capital Employed as the Dependent Variable

\begin{tabular}{|c|c|c|c|c|}
\hline \multirow{2}{*}{ Variable } & \multicolumn{2}{|c|}{ Two-Step Estimates } & \multicolumn{2}{|c|}{ One-Step Estimates } \\
\hline & Coefficient & z-Statistic & Coefficient & z-Statistic \\
\hline Intercept & 0.1786 & $15.44^{* *}$ & 0.2011 & $5.82^{* *}$ \\
\hline $\mathrm{ROCE}_{\mathrm{t}-1}$ & 0.1332 & $12.47^{* *}$ & 0.1352 & 1.49 \\
\hline $\mathrm{HHI}_{\mathrm{t}}$ & 0.1098 & $4.02^{* *}$ & 0.0722 & 0.71 \\
\hline KIRt & -0.0842 & $-9.55^{* *}$ & -0.0940 & $-2.83^{* *}$ \\
\hline $\mathrm{MA}_{\mathrm{t}-1}$ & -0.0051 & -1.57 & -0.0086 & -1.36 \\
\hline $\mathrm{ADVT}_{\mathrm{t}}$ & 0.1528 & 0.53 & 0.6391 & 0.87 \\
\hline$M A D_{t}$ & -0.8438 & $-8.63^{* *}$ & -0.9230 & $-2.59^{* *}$ \\
\hline $\mathrm{RD}_{\mathrm{t}-1}$ & -1.2895 & $-7.10^{* *}$ & -1.1472 & -1.17 \\
\hline $\mathrm{FTP}_{\mathrm{t}}$ & 0.0689 & $7.93^{* *}$ & 0.0692 & $2.31^{* *}$ \\
\hline IMEX $_{\mathrm{t}}$ & 0.0003 & 0.78 & 0.0007 & 1.20 \\
\hline Wald-Chi ${ }^{2}$ & $709.97^{* *}$ & & $37.21^{* *}$ & \\
\hline $\begin{array}{l}\text { Sargan Test for Over- } \\
\text { Identification of Restrictions }\end{array}$ & $\begin{array}{l}45.03 \\
(0.12)\end{array}$ & & & \\
\hline Arellano-Bond Test for AR (1) & $-1.49(0.13)$ & & $-1.78(0.08)$ & \\
\hline Arellano-Bond Test for AR (2) & $1.03(0.30)$ & & $1.22(0.22)$ & \\
\hline Number of Observations & 458 & & 458 & \\
\hline
\end{tabular}

Note: $\quad$ (1) ${ }^{* *}$ Significant at 5 percent; "Significant at 10 percent; (2) Significance level of test statistics for the Sargan test and Arellano-Bond test are given in the parentheses. (3) The z-statistics of one-step estimates use robust standard errors for heteroscedasticity.

Importantly, the coefficient of import-export ratio in respect of profitability is significant and positive. However, it is not significant for returns on capital employed. Alternatively, while profitability has varied directly with larger import competition vis-à-vis exports, it failed to cause any significant impact on returns on capital employed. Such differences in impact across alternative measures of performance are surprising as well as very important given that both competition from imports and export competitiveness have crucial policy implications.

\section{Concluding Remarks}

With substantial increase in M\&As after 1991, this paper examines how such integrations have affected financial performance across industries. It is found that neither M\&As nor market structure influence inter-industry variations in financial performance. However, other business strategies like foreign technology purchase and marketing and distribution related efforts as well as structural aspects like capital intensity influence firms' financial performance. While foreign technology purchase enhances financial performance, marketing and distribution related efforts and capital intensity affect the same inversely. 
Hence, there is a need to revisit the policies and laws relating to competition, international trade (especially in respect of technology imports) and technology development as they influence business strategies and enhance operational efficiency, competitiveness and financial performance. In specific, the paper suggests for a relook at the understanding of and approach to regulation of M\&As or sellers' concentration in different markets as they do not necessarily affect performance. This is very important considering that integration of (weaker) firms or access to better technology or enhancing scale of production through M\&As can enhance efficiency and restrict monopoly power. Given the industry-specific characteristics, the findings also suggest for deeper scrutiny of the existing approach for judging implications of the deals.

Further, it is also essential to examine why innovation fails to affect business performance, particularly in respect of identifying the underlying reasons and examining the efficacy of the existing policies and the patent laws. This is so because investment in innovation by domestic firms is still very low. Although innovative efforts have recorded significant growth in recent years, M\&As and inward FDI still continue as important channels of technology sourcing (Basant \& Mishra, 2016). On the contrary, protection of intellectual property may not necessarily incentivize towards innovation (Branstetter, 2004). In Indian context also, the new patent regime seems to have failed in enhancing in-house R\&D (Mishra, 2010). Appropriate technology and competition policies require addressing these aspects. Probably, integration of policy and regulatory measures with greater industryspecific flexibilities would help in reaping better outcomes. However, robust conclusions on implications of M\&As for firms' business performance require deeper scrutiny at firm level, controlling the type of deals and their size.

\section{Acknowledgement}

The views expressed in this paper are strictly the author's personal and are not associated with Institute where he works. The author had presented the earlier version of this paper in the National Conference on Economics of Competition Law organized by the Competition Commission of India (CCl) in New Delhi during 2-3 March, 2017. The author expresses his deep gratitude to the $\mathrm{CCl}$ for giving him this opportunity and providing financial support. He is thankful to the session chair, discussant of the paper and other participants of the conference for their important inputs. The author is also thankful to Prof. Rakesh Basant for having useful discussions in different stages of writing this paper. The inputs by the anonymous referees are also acknowledged for enriching the paper considerably. Thanks are also due to Mr. Aman Mahawar and Ms. Neha Jaiswal for their excellent support in compilation of data and computation of variables. Usual disclaimers apply.

\section{References}

Arellano, M., \& Bond, S. (1991). Some Tests of Specification for Panel Data: Monte Carlo Evidence and an Application to Employment Equations, The Review of Economic Studies, 58(2), 277-297. https://doi.org/10.2307/2297968 
Arellano, M., \& Bover, O. (1995). Another Look at Instrumental Variables Estimation of Error Component Models, Journal of Econometrics, 68(1), 29-51. https://doi.org/10.1016/03044076(94)01642-D

Akin, A., \& Bayyurt, N. (2016). Mode of Entry and the Performance of Foreign Banks: Evidence from Turkish Banking Industry, Eurasian Journal of Business and Economics, 9 (17), 153-164. https://doi.org/10.17015/ejbe.2016.017.09

Blundell, R., \& Bond, S. (1998). Initial Conditions and Moment Restrictions in Dynamic Panel Data Models, Journal of Econometrics, 87(1), 115-143. https://doi.org/10.1016/S03044076(98)00009-8

Bain, J. S. (1951). Relation of Profit Rate to Industrial Concentration: American Manufacturing, 1936-1940, Quarterly Journal of Economics, 65(3), 293-324. https://doi.org/10.2307/1882217

Bain, J. S. (1956). Barriers to New Competition: Their Character and Consequences in Manufacturing Industries, Cambridge: MA: Harvard University Press. https://doi.org/10.4159/harvard.9780674188037

Balcer, Y., \& Lippman, S. A. (1984).Technological Expectations and Adoption of Improved Technology, Journal of Economic Theory, 34(2), 292-318.

Basant, R., \& Saha, S. N. (2005). Determinants of Entry in the Indian Manufacturing Sector, Working Paper No 2005-01-01, Indian Institute of Management, Ahmedabad.

Basant, R., \& Mishra, P. (2016). Trends in Strategies and Performance of the Indian Corporate Sector What has Changed in Two Decades of Economic Reforms?, Working Paper No 201603-31, Indian Institute of Management Ahmedabad.

Basant, R., \& Mishra, P. (2016). Vertical Integration, Market Structure and Competition Policy: Experiences of Indian Manufacturing Sector during the Post-Reform Period, Working Paper No. 2017-09-2, Indian Institute of Management Ahmedabad.

Beena, P. L. (2014). Mergers and Acquisitions: India under Globalization, India: Routledge. https://doi.org/10.4324/9781315744032

Bhagwat, Y., \& DeBruine, M. (2011). R\&D and Advertising Efficiencies in the Pharmaceutical Industry. International Journal of Applied Economics, 8(1), 55-65.

Bhandari, A. (2010). Concentration, Entry Barriers and Profitability in the Indian Industries: An Empirical Analysis, Journal of Quantitative Economics, 8(2), 61-80.

Branstetter, L. G. (2004). Do Stronger Patents Induce More Local Innovation, Journal of International Economic Law, 7(2), 359-370. https://doi.org/10.1093/jiel/7.2.359

Cefis, E. (1998). Persistence in Profitability and in Innovative Activities, Working Paper, Bocconi University and University of Bergano.

Chatterjee, S. (1986). Types of Synergy and Economic Value: The Impact of Acquisitions on Merging and Rival Firms, Strategic Management Journal, 7(2), 119-139. https://doi.org/10.1002/smj.4250070203

Cosh, A., Hughes, A., \& Singh, A. (1984).The Causes and Effects of Takeover in the UK: An. Empirical Investigation for the Late 1960s at the Microeconomic Level, Economics Reprints No. 87, Cambridge: Department of Applied Economics, University of Cambridge.

Comanor, W. S., \& Wilson, T. A. (1967). Advertising, Market Structure and Performance, Review of Economics and Statistics, 49(4), 423-440. 
How have Mergers and Acquisitions Affected Financial Performance of Firms in Indian...

Das, N. (2000). A Study of the Corporate Restructuring of Indian Industries in the Post-New Industrial Policy Regime: The Issue of Amalgamations/Mergers', Unpublished Ph.D. Thesis, University of Calcutta, Calcutta.

Demsetz, H. (1973). Industry Structure, Market Rivalry and Public Policy, Journal of Law and Economics, 16(1), 1-9. https://doi.org/10.1086/466752

Demir, F. (2013). Growth under exchange rate volatility: Does access to foreign or domestic equity markets matter?. Journal of Development Economics, 100 (1), 74-88. https://doi.org/10.1016/j.jdeveco.2012.08.001

Delorme Jr., C. D., Kamerschen, D. R., Klein P. G., \& Voeks, L. F. (2002). Structure, Conduct and Performance: A Simultaneous Equations Approach, Applied Economics, 34(17), 21352141. https://doi.org/10.1080/00036840210135836

Dickerson, A. P., Gibson, H. D., \& Tsakalotos, E. (1997).The Impact of Acquisitions on Company Performance: Evidence from a Large Panel of UK Firms, Oxford Economic Papers, 49(3), 344-61. https://doi.org/10.1093/oxfordjournals.oep.a028613

Ghosh, A. (2001). Does Operating Performance Really Improve Following Corporate Acquisitions?. Journal of Corporate Finance, 7(2), 151-178. https://doi.org/10.1016/S09291199(01)00018-9

Geroski, P. (1988). Is Corporate Success Predictable and Does it Persist? Working Paper Series No. 48, Centre for Business Strategy, London Business School.

Goldar, B., \& Aggarwal S. C. (2004). Trade Liberalization and Price-Cost Margin in Indian Industries, Working Paper No. 130, Indian Council for Research on International Economic Relations, New Delhi.

Grabowski, H. G., \& Mueller, D. C. (1978). Industrial Research and Development, Intangible Capital Socks, and Firm Profit Rates, Bell Journal of Economics, 9(1), 328-343. https://doi.org/10.2307/3003585

Grazzi, M. (2012). Export and Firm Performance: Evidence on Productivity and Profitability of Italian Companies. Journal of Industry, Competition and Trade, 12(4), 413-444. https://doi.org/10.1007/s10842-011-0102-9

Gugler, K., Mueller, D. C., Yurtoglu, B. B., \& Zulehner, C. (2003). The Effects of Mergers: an International Comparison, International Journal of Industrial Organization, 21(5), 651. https://doi.org/10.1016/S0167-7187(02)00107-8

Hay, D., \& Morris, D. (1991). Industrial Economics and Organization (ed.), Oxford: Oxford University Press.

Healy, P. M., Palepu, K. G., \& Ruback, R. S. (1992). Do Mergers Improve Corporate Performance? Journal of Financial Economics, 31(2), 135-175. https://doi.org/10.1016/0304405X(92)90002-F

Heron, R. \& Lie, E. (2002). Operating Performance and The Method of Payment in Takeovers, Journal of Financial and Quantitative Analysis, 37(1), 137-156. https://doi.org/10.2307/3594998

Ikeda, K., \& Doi, N. (1983). The Performance of Merging Firms in Japanese Manufacturing Industry 1964-75, Journal of Industrial Economics, 31(4), 257-266. https://doi.org/10.2307/2097886

ISID (2014) FDI into India's Manufacturing Sector via M\&As: Trends and Composition, Working Paper No. 161, Institute for Studies in Industrial Development, New Delhi 
Katrak, H. (1980). Industry Structure, Foreign Trade and Price-Cost Margins in Indian Manufacturing Industries, Journal of Development Studies, 17(1), 62-79.

Kumar, M. S. (1984). Growth, Acquisition and Investment, Cambridge: Cambridge University Press.

Kambhampati, U. S. (1996). Industrial Concentration and Performance; A Study of the Structure, Conduct and Performance of Indian Industry, Delhi: Oxford University Press.

Kambhampati, U. S., \& Parikh, A. (2003). Disciplining firms: the impact of trade reforms on profit margins in Indian industry. Applied Economics, 35(4), 461-470.

Karels, G. V., Lawrence, E., \& Yu, J. (2011). Cross-border mergers and acquisitions between industrialized and developing countries. International Journal of Banking and Finance, 8(1), 35-58.

Kaur, P., \& Kaur G. (2010). Impact of Mergers on the Cost Efficiency of Indian Commercial Banks, Eurasian Journal of Business and Economics, 3 (5), 1-21.

Kongmanila, X., \& Takahashi, Y. (2009). Inter-firm cooperation and firm performance: An empirical study of the Lao garment industry cluster. International Journal of Business and Management, 4(5), 3-17. https://doi.org/10.5539/ijbm.v4n5p3

Liebowitz, S. J. (1982). What Do Census Price-Cost Margins Measure? Journal of Law and Economics, 25(2), 231-246.

Majumdar, S. (1997). The Impact of Size and Age on Firm-Level Performance: Some Evidence from India, Review of Industrial Organization. 12(2), 231-241. https://doi.org/10.1023/A:1007766324749

Manson, S., Powell, R., Stark, A.W., \& Thomas, H. M. (2000). Identifying Sources of Gains from Takeovers, Accounting Forum, 24(4), 1-25. https://doi.org/10.1111/1467-6303.00044

Mantravadi, P., \& Reddy, A. V. (2008). Post-Merger Performance of Acquiring Firms from Different Industries in India, International Research Journal of Finance and Economics, 22, 193-204.

Martin, S. (1988). Market Power and/or Efficiency?, Review of Economics and Statistics, 70(2), 331-335.

McDonald, J. T. (1999). The Determinants of Firm Profitability in Australian Manufacturing, Economic Record, 75(229), 115-126. https://doi.org/10.1111/i.1475-4932.1999.tb02440.x

Mishra, P. (2008). Concentration-Markup Relationship in Indian Manufacturing Sector, Economic and Political Weekly, 43(39), 74-81.

Mishra, P. (2010). R\&D Efforts by Indian Pharmaceutical Firms in the New Patent Regime, South East European Journal of Economics and Business, 5(2), 83-94.

Mishra, P., \& Chandra, T. (2010). Mergers, Acquisitions and Firms' Performance: Experience of Indian Pharmaceutical Industry, Eurasian Journal of Business and Economics, 3(5), 111 126.

Mishra, P., \& Vikas (2010). Structure, Conduct and Performance in Indian Pharmaceutical Industry, A Simultaneous Equations Investigation, Review of Development and Change, 15(1), 69-99.

Mishra, P., \& Rao, U. S. (2014). Concentration vs. Inequality Measures of Market Structure: An Exploration of Indian Manufacturing, Economic and Political Weekly, 49(33), 59-65. 
How have Mergers and Acquisitions Affected Financial Performance of Firms in Indian...

Mishra, P., \& Jaiswal, N. (2017) .The Impact of Mergers and Acquisitions on Firms' Export Competitiveness: Experience of Indian Pharmaceutical Industry", South Asian Economic Journal, 18(1), 1-20. https://doi.org/10.1177/1391561416661625

Mishra, P. (2018). Are Mergers and Acquisitions Necessarily Anti-Competitive? Empirical Evidence of Indian Manufacturing Sector, Margin, 12(3), 276-307.

Mitchell, M., \& J. Mulherin (1996).The Impact of Industry Shocks on Takeover and Restructuring Activity, Journal of Financial Economics, 41(2), 193- 229.

Mueller, D. C. (1985). Mergers and Market Share, Review of Economics and Statistics, 67(2), 259-267. https://doi.org/10.2307/1924725

Mueller, D. C. (1990). The Dynamics of Company Profits: an International Comparison, Cambridge: Cambridge University Press. https://doi.org/10.1017/CBO9780511664724

Newey, W. K., \& West, K. D. (1994). Automatic Lag Selection in Covariance Matrix Estimation, The Review of Economic Studies, 61(4), 631-653.

Odagiri, H. (1992). Growth through Competition, Competition through Growth: Strategic Management and the Economy in Japan, Oxford: Clarendon Press.

Pawaskar, V. (2001). Effects of Mergers on Corporate Performance, Vikalpa, 26(1), 19-32. https://doi.org/10.1177/0256090920010304

Porter, M. E. (1985). The Competitive Advantage, New York: The Free Press.

Powell, R. G., \& Stark, A. W. (2005). Do Takeovers Create 'Real'Gains? Some UK Evidence, Working Paper, University of New South Wales, Sydney, Australia.

Pradhan, J. P. (2008). The Evolution of Indian Outward Foreign Direct Investment: Changing Tends and Patterns, International Journal of Technology and Globalization, 4(1), 70-86.

Rahman, A. R., \& Limmack, R. J. (2004). "Corporate Acquisition and the Operating Performance of Malaysian Companies", Journal of Business Finance and Accounting, 31(3-4), 359-400.

Ravenscraft, D. J. (1983). Structure-Profit Relationships at the Line of Business and Industry Level, Review of Economics and Statistics, 65(1), 22-31. https://doi.org/10.2307/1924405

Ravenscraft, D. J., \& Scherer, F. M. (1987). Life after Takeover, The Journal of Industrial Economics, 36(2), 147-156. https://doi.org/10.2307/2098409

Saluja, M. R. (1968). Structure of Indian Economy: Inter-Industry Flows and Pattern of Final Demands 1964-65, Sankhya, Series B, 30(1-2), 97-122.

Saple, V. (2000). Diversification, Merger and their Effect on Firm Performance: A Study of the Indian Corporate Sector, Unpublished Ph.D. Thesis, Indira Gandhi Institute of Development Research, Mumbai.

Sargan, J. D. (1958). The Estimation of Economic Relationships using Instrumental Variables, Econometrica: Journal of the Econometric Society, 26(3), 393-415. https://doi.org/10.2307/1907619

Schenk, H. (2006). Mergers and Concentration Policy in Bianchi, P. and Labory, S. (Ed.), International Handbook of Industrial Policy, Cheltenham: Edward Elgar.

Scherer, F. M., \& Ross, D. (1990). Industrial Market Structure and Economic Performance, Chicago: Rand Mcnally.

Scherer, F. M. (2001). The Link between Gross Profitability and Pharmaceutical R\&D Spending, Health Affairs, 20 (5), 216-220. https://doi.org/10.1377/hlthaff.20.5.216 
Sharma, D.S., \& Ho, J. (2002). The Impact of Acquisitions on Operating Performance: Some Australian Evidence, Journal of Business Finance \& Accounting, 29(1-2), 155-200.

Shelton, L. M. (1988). Strategic Business Fits and Corporate Acquisitions: Empirical Evidence, Strategic Management Journal, 9(3), 279-287.

Siddharthan, N. S., \& Dasgupta A. K. (1983). Entry Barriers, Exports, and Inter-Industry Differences in Profitability, Developing Economies, 21(1), 14-23.

Smart, S. B., \& Waldfogel, J. (1994). Measuring the Effect of Restructuring on Corporate Performance: The Case of Management Buyouts, Review of Economics and Statistics, 76(3), 503-511.

Steiner, P. O. (1975). Mergers, Motives, Effects and Policies, Ann Arbor, MI: University of Michigan Press.

Stigler, G. J. (1950). Monopoly and Oligopoly by Merger, American Economic Review, 40(2), 23-34.

Stigler, G. J. (1964). A Theory of Oligopoly, Journal of Political Economy, 72(1), 44-61. https://doi.org/10.1086/258853

Saraswathy, B. (2015). Production Efficiency of Firms with Mergers and Acquisitions in India, Working Paper No. 299, Indian Council for Research on International Economic Relations, New Delhi.

Switzer, J. A. (1996). Evidence of Real Gains in Corporate Acquisitions, Journal of Economics and Business, 48(5), 443-60. https://doi.org/10.1016/S0148-6195(96)00033-1

Tyagi, S., \& Nauriyal, D. (2016). Profitability Determinants in Indian Drugs and Pharmaceutical Industry: An Analysis of Pre and Post TRIPS Period, Eurasian Journal of Business and Economics, 9 (17), 1-21. https://doi.org/10.17015/ejbe.2016.017.01

Vander, V. R. (1996). The Effect of Mergers and Acquisitions on the Efficiency and Profitability of EC Credit Institutions, Journal of Banking and Finance, 20(9), 1531-1558.

Vu, H., Holmes, M., Lim, S., \& Tran, T. (2014). Exports and profitability: a note from quantile regression approach. Applied Economics Letters, 21(6), 442-445. https://doi.org/10.1080/13504851.2013.866197

Vyas, V., Narayanan, K., \& Ramanathan A. (2012). Determinants of mergers and acquisitions in Indian pharmaceutical industry. Eurasian Journal of Business and Economics, 5(9), 79-102.

Wagner, J. (2012). Exports, imports and profitability: First evidence for manufacturing enterprises. Open Economies Review, 23(5), 747-765. https://doi.org/10.1007/s11079-0119235-z

Weiss, L. W. (1974). The Concentration-Profits Relationship and Antitrust' in H J Goldschmid, H Michael Mann and J Fred Weston (eds), Boston: Industrial Concentration, The New Learning; Little Brown.

Williamson, O. (1968) .Economies as an Antitrust Defense: The Welfare Tradeoffs, The American Economic Review, 58(1), 18-36.

Yeh, T. M., \& Hoshino, Y. (2002). Productivity and Operating Performance of Japanese Merging Firms: Keiretsu-Related and Independent Mergers, Japan and World Economy, 14 (3), 347-366. https://doi.org/10.1016/S0922-1425(01)00081-0

Zhu, P., \& Malhotra, S. (2008). Announcement effect and price pressure: an empirical study of cross-border acquisitions by Indian firms. International Research Journal of Finance and Economics, 13(1), 24-41. 